\title{
A Study on Quarter-wise Incidence of Mastitis in Dairy Animals and Antibiogram of Associated Bacteria
}

\author{
Vipul Thakur ${ }^{1}$, Naresh Jindal ${ }^{2}$, D. S. Dahiya ${ }^{3}$ and Pankaj Kumar ${ }^{4 *}$ \\ ${ }^{1}$ Department of Veterinary Medicine, COVAS, SVPUAT, Meerut (UP), India \\ ${ }^{2}$ Department of Veterinary Public Health and Epidemiology, College of Veterinary \\ Sciences, LUVAS, Hisar (Haryana), India \\ ${ }^{3}$ LUVAS-Pashu Vigvan Kendra, Bhiwani (Haryana), India \\ ${ }^{4}$ LUVAS-Disease Investigation Laboratory, Rohtak (Haryana), India \\ *Corresponding author
}

\section{A B S T R A C T}

\section{Keywords}

Mastitis, Quarter-

wise, Species-wise,

Bovines,

Antibiogram, White

Side Test, WST,

Incidence

\section{Article Info}

Accepted:

12 January 2021

Available Online:

10 February 2021
The present study was done on milk samples collected from the 469 milch animals (1765 quarters/teats), of which 296 were buffaloes (1120 quarters) and 173 were cows (645 quarters) at Disease Investigation Laboratory (DI lab), Bhiwani during the period from July, 2016 to June, 2017to know quarter-wise association of mastitis in bovines and to understand current susceptibility pattern of the isolates to various antibacterial drugs. Overall prevalence was observed to be $42.86 \%$ by WST. Species-wise higher percentage of cows $(47.40 \%)$ were positive for mastitis compares to buffaloes (40.20\%). Among the affected animals, the maximum were having only single quarter infection among both species i.e., $35.47 \%$ of cows and $41.18 \%$ of buffaloes. Incidence observed on front quarters and hind quarters basis lead to the inference that hind quarters $(32.31 \%)$ are more prone to mastitis than front quarters $(15.46 \%)$. At species level also, higher incidences were noted in hind quarters. The result leads to inference that the hind quarters are more susceptible to mastitis than the front quarters. Categorization of data according to position of four teats/quarters viz., left hind, right hind, left front and right front quarter, overall as level at species level basis right hind quarter was having the highest prevalence while left front quarter was found to be the least affected by mastitis. In bacteriological examination total177 $(88.06 \%)$ milk samples were found to be positive in cultural examination. Of the examined samples $37(84.09 \%)$ of cows while $140(89.17 \%)$ of buffaloes, respectively, were positive for microbial isolation. On Gram's staining it was observed that the majority of isolates were Gram-positive bacteria $(59.89 \%)$. Based on colony and morphological characteristics among the Gram-positive bacteria Staphyloccocus sp. bacteria were the major pathogens while $E$. coli was the major pathogen amongst the Gramisolates. The antibiotic sensitivity pattern of isolates was a studied. Ceftriaxone-sulbactum was found to be the most effective $(92.09 \%)$ among the tested antibiotics followed by enrofloxacin $(90.39 \%)$ while Penicillin-G was found to be least effective $(11.30 \%)$ among the battery of antibiotics tested. The present study lead to the inference that there is association of mastitis with position of quarter and the pathogens associated with the disease are developing resistant to the commonly used antibiotics. Hence, the animal health workers must recommend antibiotic sensitivity testing so that effective and judicious use of antibiotics can be done. Dairy farmers should adopt scientific methods of animal husbandry in order to achieve profitable and hygienic milk production. 


\section{Introduction}

Mastitis, a disease of complex etiology, had been recognized for more than a century, and still continues to be an evergreen cause of economic loss to the dairy industry and is the costliest problem all over the world where dairying is practiced Devi and Dutta (2018); Patil et al., (2000); Singh (2003). Mastitis is a complex disease resulting from the interaction of infectious agents and poor managemental practices in dairy animals (Schalm and Woods, 1953). The disease is known to cause a great deal of loss or reduction of productivity. It influences the quality and quantity of milk, and causes culling of animals at an unacceptable age (Mungube et al., 2005).

Therefore, keeping these points in view the importance of subclinical mastitis with its negative impact on dairy industry this study was undertaken to update available information and to further understand epidemiology of mastitis in the area under study. The present study was done to know quarter-wise association of mastitis in bovines and to understand current susceptibility pattern of the isolates to various antibacterial drugs.

\section{Materials and Methods}

\section{Ethical approval}

The present study was carried on samples collected from animals suspected to be suffering from mastitis. For the collection of clinical milk samples approval of Institutional Animal Ethics Committee was not required as per University rules.

\section{Samples collection and processing}

Milk samples were collected from the 469 bovines (1765 quarters/teats), of which 296 were buffaloes (1120 quarters) and 173 were cows (645 quarters) at Disease Investigation Laboratory (DI lab), Bhiwani during the period from July, 2016 to June, 2017 (Table $1)$.

From each teat $10 \mathrm{ml}$ milk sample was collected in a sterile vial from animals having problems like sudden decrease in milk yield, change in colour, any other physical appearance like change in viscosity etc as reported by livestock owners and were screened by White Side test (WST) as per procedure described by Kahir et al., (2008).

The sample positive for WST was subjected to cultural examination, only one sample per animal was used for cultural examination, for this milk samples of all positive teats from one animal were mixed and then processed for bacteriological examination.

The isolates were identified according to cultural and morphological characteristics complying with methods of Cruickshank et al., (1975). All culture media and antibiotic discs used were manufactured by HiMedia laboratories Pvt. Ltd, Pune.

The in vitro antibiotic sensitivity pattern was studied by Kirby-Bauer disc diffusions method with slight modifications (Bauer et al., 1966) using 09 number of standard antibiotic discs (HiMedia laboratories Pvt. Ltd.) such as Amoxicillin, Amoxicillinsulbactum, Cefoperazone, Ceftriaxone, Ceftriaxone-sulbactum, Chloramphenicol, Enrofloxacin, Penicillin-G, Streptomycin and Tetracycline.

The interpretation regarding the degree of susceptibility (resistant, moderate and highly sensitive) was made as per Clinical and Laboratory Standards Institute (NCCLS, 1999) chart provided by the antibiotic disc manufacturer. 


\section{Results and Discussion}

\section{Overall and Species wise prevalence}

Overall combined prevalence of $42.86 \%$ was observed by WST (Table 1). On Species-wise analysis of data it was seen higher percentage of cows $(47.40 \%)$ were positive for mastitis with respect to buffaloes $(40.20 \%)$. This was in agreement to the earlier report of Thapa and Kaphle (2002) who reported that buffaloes to be less susceptible to mastitis than cattle. Mustafa et al., (2011) also recorded lower prevalence of mastitis in buffalo (20.98\%) compares to cows (24.71 $\%)$. The lower prevalence rate in buffalo has been ascribed to more perfect sphincter mechanism, which prevents entry of infection into teat canal (Uppal et al., 1994). Similar, to the present study higher quarter prevalence in cows haven reported by various workers (Jingar et al., 2014; Kumar et al., 2015; Swami et al., 2017; Yadav et al., 2019)

\section{Quarter-wise prevalence}

\section{Number of quarter involved per animal}

Data of the affected animals was analysed with respect to number of quarters involved per animal and it was observed that maximum number of animals were having only single quarter i.e., $35.47 \%$ of cows and $41.18 \%$ of buffaloes while affected animals having all four quarters infected were lowest. The annotations of the present report are in concord with those of Patel and Trivedi, (2015); Yadav et al., (2019); Thakur et al., (2020); who in their independent studies reported that maximum number of animals had single quarter infection, followed by two quarters, three quarters and all four quarters infection in decreasing order. However, Dasohari et al., (2017) observed that the maximum number of animals was having two quarter infection followed by single, three and four quarters infection. The fact that single quarter infection had higher incidence is an indication that possibly one quarter is usually first infected and the others become affected through contamination and other means especially during the milking procedures (Shittu et al., 2012). The difference in quarter wise prevalence might be due to the fact that predisposing factors like injury, defective sphincters, and so forth could vary from quarter to quarter Iqbal and Siddique (1999).

\section{Prevalence based on position of quarter}

Incidence was also observed on front quarters and hind quarters basis (Table 2); higher incidence was detected in hind quarters $(32.31 \%)$ than front quarters $(15.46 \%)$. At species level also, higher incidences were noted in hind quarters both in cows $(37.57 \%)$ and buffaloes (29.00\%) with respect to front quarters; $17.82 \%$ and $14.19 \%$ in cows and buffaloes, respectively. The result leads to inference that the hind quarters are more susceptible to mastitis than the front quarters. These findings are in agreement with those Sharma et al., (2012), Yadav et al., (2019) who all published reports with higher incidence(s) in hind quarters. Contrary, to our observations Patel and Trivedi (2015), noted higher prevalence in front quarters than hind quarters.

On analysis of data according to position of four teats/quarters viz., left hind, right hind, left front and right front quarter and it was found that overall basis right hind quarter was having highest prevalence (36.09\%) and while over left front quarter $(14.35 \%)$ was least affected by mastitis. These observations were also valid at species level for both cows and buffaloes. In accord to our observations, Zenebe et al., (2014), also find thatright hind quarters have the highest infection rate $(63.9 \%)$ and lowest infection rate in left front quarters (40.4\%). Similarly, reports of Thakur 
et al., 2020 from Haryana and Manokaran et al., 2020 were in concurrence with the results of the present study.

This could be attributed to the high production capacity of the hind quarters (Radostits et al., 2007) and due to the larger mass, greater vulnerability to direct trauma, relatively more closeness to the floor as compared to front quarters, hence high chance of getting faecal, urine and environmental contamination (Hase et al., 2013).Contrary, to our observations Patel and Trivedi, (2015), noted higher prevalence in front quarters than hind quarters.

Table.1 Overall incidence of mastitis in relation to number of quarters involved in affected animals

\begin{tabular}{|c|c|c|c|c|c|c|c|c|}
\hline \multirow[t]{2}{*}{ Species } & \multirow[t]{2}{*}{$\begin{array}{c}\text { Total } \\
\text { Animals }\end{array}$} & \multirow[t]{2}{*}{$\begin{array}{c}\text { Positive } \\
(\%)\end{array}$} & \multirow[t]{2}{*}{$\begin{array}{c}\text { Total } \\
\text { Quarters }\end{array}$} & \multirow[t]{2}{*}{$\begin{array}{c}\text { Positive } \\
(\%)\end{array}$} & \multicolumn{4}{|c|}{$\begin{array}{c}\text { Number of Quarters Involved } \\
\text { animal-wise }\end{array}$} \\
\hline & & & & & One $(\%)$ & $\begin{array}{l}\text { Two } \\
(\%)\end{array}$ & $\begin{array}{c}\text { Three } \\
(\%)\end{array}$ & $\begin{array}{l}\text { Four } \\
(\%)\end{array}$ \\
\hline Cow & 173 & $\begin{array}{c}82 \\
(\mathbf{4 7 . 4 0 )}\end{array}$ & $645^{*}$ & $\begin{array}{c}177 \\
(27.44)\end{array}$ & $\begin{array}{c}29 \\
(35.37)\end{array}$ & $\begin{array}{c}23 \\
(28.05)\end{array}$ & $\begin{array}{c}18 \\
(21.95)\end{array}$ & $\begin{array}{c}12 \\
(\mathbf{1 4 . 6 3})\end{array}$ \\
\hline Buffalo & 296 & $\begin{array}{c}119 \\
(40.20)\end{array}$ & $1120 * *$ & $\begin{array}{c}233 \\
(20.80)\end{array}$ & $\begin{array}{c}49 \\
\mathbf{( 4 1 . 1 8})\end{array}$ & $\begin{array}{c}37 \\
(31.09)\end{array}$ & $\begin{array}{c}22 \\
(18.49)\end{array}$ & $\begin{array}{c}11 \\
(9.24)\end{array}$ \\
\hline Total & 469 & $\begin{array}{c}201 \\
(\mathbf{4 2 . 8 6})\end{array}$ & 1765 & $\begin{array}{c}410 \\
(23.23)\end{array}$ & $\begin{array}{c}78 \\
(\mathbf{3 8 . 8 1})\end{array}$ & $\begin{array}{c}60 \\
(29.85)\end{array}$ & $\begin{array}{c}40 \\
(19.90)\end{array}$ & $\begin{array}{c}23 \\
(\mathbf{1 1 . 4 4})\end{array}$ \\
\hline \multicolumn{5}{|c|}{$645=4 * 39+3 * 21+2 * 13$} & \multicolumn{4}{|c|}{$1120=4 * 247+3 * 34+2 * 15$} \\
\hline
\end{tabular}

Table.2 Incidence of mastitis in front quarters and hind quarters

\begin{tabular}{|c|c|c|c|c|}
\hline & Hind quarters & Positive (\%) & Front Quarters & Positive (\%) \\
\hline Species & & & & \\
\hline Cow & 314 & $118(37.57)$ & 331 & $59(17.82)$ \\
\hline Buffalo & 500 & $145(29.00)$ & 620 & $88(14.19)$ \\
\hline Total & 814 & 263 & 951 & $147(15.46)$ \\
\hline
\end{tabular}

Table.3 Quarter-wise prevalence of subclinical mastitis

\begin{tabular}{|c|c|c|c|c|c|c|c|c|c|c|}
\hline Species & $\begin{array}{c}\text { Quarters } \\
\text { Tested }\end{array}$ & $\begin{array}{c}\text { Positive } \\
(\%)\end{array}$ & LH & $\begin{array}{c}\text { Positive } \\
(\%)\end{array}$ & RH & $\begin{array}{c}\text { Positive } \\
(\%)\end{array}$ & $\mathbf{L F}$ & $\begin{array}{c}\text { Positive } \\
(\%)\end{array}$ & RF & $\begin{array}{c}\text { Positive } \\
(\%)\end{array}$ \\
\hline Cow & 645 & $\begin{array}{c}177 \\
(\mathbf{2 7 . 4 4 )}\end{array}$ & 158 & $\begin{array}{c}53 \\
(33.54)\end{array}$ & 156 & $\begin{array}{c}65 \\
(41.67)\end{array}$ & 167 & $\begin{array}{c}28 \\
\mathbf{( 1 6 . 7 7 )}\end{array}$ & 164 & $\begin{array}{c}31 \\
(18.90)\end{array}$ \\
\hline Buffalo & 1120 & $\begin{array}{c}233 \\
(20.80)\end{array}$ & 257 & $\begin{array}{c}66 \\
(25.68)\end{array}$ & 243 & $\begin{array}{c}79 \\
(\mathbf{3 2 . 5 1})\end{array}$ & 314 & $\begin{array}{c}41 \\
(\mathbf{1 3 . 0 6})\end{array}$ & 306 & $\begin{array}{c}47 \\
(15.36)\end{array}$ \\
\hline Total & 1765 & $\begin{array}{c}410 \\
(\mathbf{2 3 . 2 3})\end{array}$ & 415 & $\begin{array}{c}119 \\
(28.67)\end{array}$ & 399 & $\begin{array}{c}144 \\
(\mathbf{3 6 . 0 9})\end{array}$ & 481 & $\begin{array}{c}69 \\
(\mathbf{1 4 . 3 5})\end{array}$ & 470 & $\begin{array}{c}78 \\
(16.60)\end{array}$ \\
\hline \multicolumn{5}{|c|}{$645=4 * 39+3 * 21+2 * 13$} & \multicolumn{6}{|c|}{$1120=4 * 247+3 * 34+2 * 15$} \\
\hline
\end{tabular}


Table.4 Categorization of bacteria isolated based on Gram's staining

\begin{tabular}{|c|c|c|c|}
\hline & Cow & Buffalo & Overall \\
\hline Bacteria & & & \\
\hline Gram's positive & 23 & 83 & 106 \\
& $(62.16 \%)$ & $(59.29 \%)$ & $(59.89 \%)$ \\
\hline Gram's negative & 14 & 57 & 71 \\
& $(37.84 \%)$ & $(40.71 \%)$ & $(40.11 \%)$ \\
\hline Total & 37 & 140 & 177 \\
\hline
\end{tabular}

Table.5 Antibiogram of bacterial isolates

\begin{tabular}{|c|c|c|c|c|c|c|c|c|c|c|}
\hline \multirow[t]{2}{*}{ Organism } & \multirow[b]{2}{*}{$\mathbf{E}$} & \multirow[b]{2}{*}{ Am } & \multirow[b]{2}{*}{$\mathbf{P}$} & \multirow[b]{2}{*}{$\mathbf{A S}$} & \multirow[b]{2}{*}{ CS } & \multirow[b]{2}{*}{ CPZ } & \multirow[b]{2}{*}{ CTR } & \multirow[b]{2}{*}{ Ch } & \multirow[b]{2}{*}{$\mathbf{T}$} & \multirow[b]{2}{*}{$\mathbf{S}$} \\
\hline & & & & & & & & & & \\
\hline $\begin{array}{l}\text { Gram } \\
\text { Positive }\end{array}$ & $\begin{array}{c}96 \\
(90 . \\
57)\end{array}$ & $\begin{array}{c}23 \\
(21.70)\end{array}$ & $\begin{array}{c}13 \\
(12.26)\end{array}$ & $\begin{array}{c}81 \\
(76.41)\end{array}$ & $\begin{array}{c}98 \\
(92.45)\end{array}$ & $\begin{array}{c}93 \\
(87.73)\end{array}$ & $\begin{array}{c}92 \\
(86.79)\end{array}$ & $\begin{array}{c}95 \\
(89.62)\end{array}$ & $\begin{array}{c}67 \\
(63.20)\end{array}$ & $\begin{array}{c}47 \\
(44.34)\end{array}$ \\
\hline $\begin{array}{c}\text { Gram } \\
\text { Negative }\end{array}$ & $\begin{array}{c}64 \\
(90 . \\
14)\end{array}$ & $\begin{array}{c}14 \\
(19.72)\end{array}$ & $\begin{array}{c}7 \\
(9.86)\end{array}$ & $\begin{array}{c}52 \\
(73.24)\end{array}$ & $\begin{array}{c}65 \\
(91.55)\end{array}$ & $\begin{array}{c}62 \\
(87.32)\end{array}$ & $\begin{array}{c}61 \\
(85.92)\end{array}$ & $\begin{array}{c}63 \\
(88.73)\end{array}$ & $\begin{array}{c}42 \\
(59.15)\end{array}$ & $\begin{array}{c}32 \\
(45.07)\end{array}$ \\
\hline Total & $\begin{array}{l}160 \\
(90 . \\
39)\end{array}$ & $\begin{array}{c}37 \\
(20.90)\end{array}$ & $\begin{array}{c}20 \\
(11.30)\end{array}$ & $\begin{array}{c}133 \\
(75.14)\end{array}$ & $\begin{array}{c}163 \\
(92.09)\end{array}$ & $\begin{array}{c}155 \\
(87.57)\end{array}$ & $\begin{array}{c}153 \\
(86.44)\end{array}$ & $\begin{array}{c}158 \\
(89.26)\end{array}$ & $\begin{array}{c}109 \\
(61.58)\end{array}$ & $\begin{array}{c}79 \\
(44.63)\end{array}$ \\
\hline \multicolumn{2}{|c|}{$\mathbf{E}=$ Enrofloxacin } & \multicolumn{2}{|c|}{ Am = Amoxicillin } & \multicolumn{2}{|c|}{$\mathbf{P}=$ Penicillin-G } & \multicolumn{2}{|c|}{$\begin{array}{c}\text { AS }=\text { Amoxicillin- } \\
\text { sulbactum }\end{array}$} & \multicolumn{3}{|c|}{$\begin{array}{l}\text { CS= Ceftriaxone- } \\
\text { sulbactum }\end{array}$} \\
\hline \multicolumn{2}{|c|}{$\begin{array}{l}\mathrm{CPZ}= \\
\text { Cefoperazone }\end{array}$} & \multicolumn{2}{|c|}{$\begin{array}{c}\text { CTR= } \\
\text { Ceftriaxone }\end{array}$} & \multicolumn{2}{|c|}{$\begin{array}{c}\mathrm{Ch}=\begin{array}{c}\text { Chloramphe } \\
\text { nicol }\end{array} \\
\text {. }\end{array}$} & \multicolumn{2}{|c|}{$\mathbf{T}=$ Tetracyclin } & \multicolumn{3}{|c|}{$\mathbf{S}=$ Streptomycin } \\
\hline
\end{tabular}

\section{Cultural examination}

Microbial cultural examination of 201milk samples, of which 44 were cow milk samples and 157 were buffalo milk samples was carried out and organisms were characterized based on Gram's staining and antibiotic sensitivity pattern of the isolates was determined.

Total of $177(88.06 \%)$ milk samples were found to be positive in cultural examination. Of the examined samples $37(84.09 \%)$ of cows while $140(89.17 \%)$ of buffaloes, respectively, were positive for microbial isolation (Table 3).

Gram's staining was done and it was observed overall majority of isolates were Gram- positive bacteria (59.89\%) as well as for both cows $(62.16 \%)$ and buffaloes (59.29\%). These observations are in agreement with those of Thakur et al., 2020 who instituted that majority of bacterial isolates associated with mastitis are Gram-positive.

Based on colony and morphological characteristics among the Gram-positive bacteria Staphylococcus sp. bacteria were the major pathogens while $E$. coli was the major organism among the Gram-negative bacteria. Zeryehun and Abera (2017) in their study found Staphylococcus species predominant species (Table 4).

Bhalerao et al., (2000) and Zenebe et al., (2014)in their studies have also observed overall predominance of Staphyloccocus sp. 
among the organisms isolated from subclinical mastitis positive samples and also Escherichia coli as major pathogen among the Gram's negative bacteria which are in agreement with the present study.

The high prevalence of Staphylococcus sp. may be associated with its frequent colonization of teats, its ability to exist intracellular and localize within micro abscesses in the udder and hence resistant to antibiotic treatment (MacDonald, 1997). The organism is well adapted to survive in the udder and usually establishes a mild sub clinical infection of long duration from which it shed in milk facilitating trans-mission to healthy animals mainly during milking (Radostits et al., 2007).

\section{Antibiogram}

Invitro antibiotic sensitivity pattern of isolates was also studied. Ceftriaxone-sulbactum was found to be the most effective (92.09\%) among the tested antibiotics followed by enrofloxacin $(90.39 \%)$ while Penicillin-G was found to be least effective $(11.30 \%)$ among the battery of antibiotics tested (Table 5). However, Thakur et al., 2020 and Jeykumar et al., 2013 found enrofloxacin to be the most effective antibiotics while Penicillin $G$ was found to be least effective by invitro sensitivity test. Bhat et al., (2017) also found enrofloxacin to be the most effective against the mastitis causing pathogens. The alarming level of less susceptibility or more resistance of organisms to a particular drug might be due to the prolonged exposure to the same drug and due to indiscriminate use. This high emergence of resistance to commonly used antibiotics is not surprising as there is irrational use of these antibiotics due to lack of cultural antibiotic sensitivity practice before treatment (Jeykumar et al., 2013).

In conclusion the buffalo and cattle are mostly reared for milk production. A disease, mastitis renders them useless for this purpose. Milk production usually decreases and blood alone or mixed with mucus in milk. It is one of the most important reasons for termination of lactation and unwanted culling of dairy buffalo

The present study lead to the inference that there is association of mastitis with position of quarter and the pathogens associated with the disease are developing resistant to the commonly used antibiotics. The control of mastitis can be achieved by a definite regime of administration of antibiotics and holistic approach to the disease management. Hence, the animal health workers must recommend antibiotic sensitivity testing so that effective and judicious use of antibiotics can be done. Dairy farmers should adopt scientific methods of animal husbandry in order to achieve profitable and hygienic milk production.

\section{References}

Bauer, A.W., Kirby, W.M., Sherriz, J.C. and Tuck, N.1996. Antibiotic susceptibility testing by standardized single disc method. American J. Clin. Pathol. 45: 493-496.

Bhalerao, D. P., Jagadish, S., Keskar, D. V., Dangore, A. D. and Sharma, L. K. 2000. Antibiogram and treatment of bovine subclinical mastitis. Indian Vet. J. 77: 244-246.

Bhat, A.M., Soodan, J.S., Singh, R. and Bhat, T.H. 2017. Studies on isolation of pathogens causing sub-clinical mastitis in cross bred dairy cattle and their antibiogram. Indian Vet J. $94: 41$ - 43.

Cruickshank, R., Duguid, J.P., Marmion, B.P. and Swain, R.H.A. 1975. Medical Microbiology. Vol. II, 12th Ed, Churchill Livingstone, New York. 3157 and 96-218.

Dasohari, A., Somasani, A., Nagaraj, P. and Gopala, R. A. 2017. Epidemiological studies of subclinical mastitis in cows in 
and around Hyderabad. The Pharma. Innov. J. 6: 975-979.

Devi, M. and Dutta, J.B. 2018. Incidence of bovine subclinical mastitis in organized and unorganized farms based on somatic cell count. Int. J. Chem. Studies. 6: 1399-1403.

Hase, P., Digraskar, S., Ravikanth, K., Dandale, M. and Maini, S. 2013. Management of subclinical mastitis with mastilep gel and herbal spray (AV/AMS/15). Int. J. Pharm. 2: 64-67.

Iqbal, J. and Siddique, M. 1999. Some epidemiological aspects of mastitis in cows and bio characterization of isolated Staphylococci. Pakistan Vety J.19:149-154.

Jeykumar, M., Vinodkumar, G., Bashir, B.P. and Krovvidi, S. 2013. Antibiogram of mastitis pathogens in the milk of crossbred cows in Namakkal district, Tamil Nadu. Vet World. 6: 354-356. doi:10.5455/vetworld.2013.354-356.

Jingar, S.C., Mehla, R.K., Singh, M., Kumar, A., Kantwa, S.C. and Singh, N. 2014. Comparative study on the incidence of mastitis during different parities in cows and buffaloes. Indian J Anim Res. 48: 194-197.

Kahir, M.A., Islam, M.A., Rahman, A.K.M.A., Nahar, A., Rahman, M.S. and Song, H.J. 2008. Prevalence and risk factors of subclinical bovine mastitis in some dairy farms of Sylhet district of Bangladesh. Korean $\mathrm{J}$ Vet Services.31: 497-504.

Kumar, S., Suresh, R.V. and Ranjithkumar, M. 2015. Study on quarter-wise comparative prevalence, etiology and antibiogram of bovine subclinical mastitis. Int. J. of Current Res. 7: 11627-11631.

MacDonald, U.S.1997. Streptococcal and Staphylococcal mastitis. J. Am. Vet. Med. Assoc. 170:1157.

Manokaran, S., Kavithaa, N.V. and Geetha, T.
2020. A Field Study on Prevalence of Subclinical Mastitis in Indigenous Kangayam Cows. Int. J. Curr. Microbiol. App. Sci. 9: 1809-1813.

Mungube, E.D., Tenghagen, B.A., Regassa, F., Kyule, M.N., Shiferaw, Y. and Kassa, T. 2005. Reduced milk production in udder quarters with subclinical mastitis and associated economic losses in crossbred dairy cows in Ethiopia. Trop Anim Health and Prod. 37: 503-512.

Mustafa, Y.S., Awan, F.N., Zaman, T., Chaudhry, S.R. and Zoyfro, V. 2011. Prevalence and antibacterial susceptibility in mastitis in buffalo and cow in and around the district Lahore, Pakistan. Pak. J. Pharm. 24 (1 \& 2) 2933.

National Committee for Clinical Laboratory Standards (NCCLS). 1999. Performance Standards for Antimicrobial Susceptibility Testing. Ninth Informational Supplement, M100-S9, National Committee for Clinical Laboratory Standards, Wayne, Pa, USA. Patel, Y.G. and Trivedi, M.M. 2015. Quarterwise prevalence of subclinical mastitis in crossbred cows. Trends in Biosciences. 8: 4727-4729.

Patil, A.A., Mukta, A.P., Nighat, N.K., Kalorey, D.R. and Kurkure, N.V. 2000. Prevalence of subclinical mastitis and its impact on economy of livestock sector Dairy guide. 3:71.

Radostits, O.M., Gay, C.C., Hinchcliff, K.W. and Constable, P.D. 2007. Veterinary Medicine. A Textbook of the Diseases of Cattle, Sheep, Pigs, Goats and Horses, 10th ed., Saunders Elsevier, Spain, pp. 1045-1046.

Schalm, O.W. and Woods, G.M. 1953. Micrococcus pyogenes in bovine milk II. Relationship of shedding characteristics to occurrence of clinical mastitis. Am J Vet. Res.14:543-536. 
Sharma, A., Pankaj, Chhabra, R. and Sindhu, N. 2012. Prevalence of subclinical mastitis in cows: its etiology and antibiogram. Indian J. Anim. Res.46:348-353.

Shittu, A., Abdullahi, J., Jibril, A., Mohammed, A.A. and Fasina, F.O. 2012. Sub clinical mastitis and associated risk factors on lactating cows in the Savannah Region of Nigeria. BMC Veterinary Research. 8: 134.

Singh, D.K. 2003. Soluble factors involved in Immunity to bovine mastitis. In Proceedings of 4th Round Table Conference on Mastitis. 12-18.

Sori, H., Zerihun, A. and Abdicho, S. 2005. Dairy cattle mastitis in and around Sebeta. Ethiopia. Intl. J. Appl. Res. Vet. Med. 3:332-338.

Swami, S.V., Patil, R.A. and Gadekar, S.D. 2017. Studies on prevalence of subclinical mastitis in dairy animals. $J$. Entomol. Zool. Stud. 5: 1297-1300.

Thakur, V., Jindal, N., Dahiya, D.S. and Kumar, P.2020. Quarter-wise Incidence of Mastitis in Bovines and Antibiotic Sensitivity Pattern of Associated Bacterial Pathogens. The Pharma.
Innov. J. 9:372-375.

Thapa, B.B. and Kaphle, K. 2002. Selecting different drug combinations for control of Bovine clinical mastitis. J. Anim. Vet. $A d v .1: 18-21$.

Uppal, S.K., Singh, K.B., Roy, K.S., Nauriyal, D.C. and Bansal, K.B. 1994. Natural defence mechanism against mastitis: A comparative histomorphology of buffalo and cow teat canal. Buffalo J. 2: 125-131.

Yadav, R., Kumar, P. and Sandeep. 2019. Prevalence of Bovine Subclinical Mastitis in Mahendergarh and Rewari districts of south Haryana. Haryana Vet. 58: 97-100.

Zenebe, N., Habtamu, T. and Endale, B. 2014. Study on bovine mastitis and associated risk factors in Adigrat, Northern Ethiopia. African J Microbiol. Res. 8: 327-331.

Zeryehun, T. and Abera, G. 2017. Prevalence and Bacterial Isolates of Mastitis in Dairy Farms in Selected Districts of Eastern Harrarghe Zone, Eastern Ethiopia. $J$ Vet Med. 17. https://doi.org/10.1155/2017/6498618

\section{How to cite this article:}

Vipul Thakur, Naresh Jindal, D. S. Dahiya and Pankaj Kumar. 2021. A Study on Quarter-wise Incidence of Mastitis in Dairy Animals and Antibiogram of Associated Bacteria. Int.J.Curr.Microbiol.App.Sci. 10(02): 1327-1334. doi: https://doi.org/10.20546/ijcmas.2021.1002.157 